\title{
Pattern Analysis of Voice Onset and Offset in Normal Adults Using High-Speed Digital Imaging: The Role of Arytenoid Cartilage Movements
}

\author{
Seong Hee Choi ${ }^{\mathrm{a}, \mathrm{b}, \mathrm{c}}$, Chi-Sun $\mathrm{Oh}^{\mathrm{a}}$, Chul-Hee Choi ${ }^{\mathrm{a}, \mathrm{b}, \mathrm{c}}$ \\ ${ }^{a}$ Department of Audiology \& Speech-Language Pathology, Catholic University of Daegu, Gyeongsan, Korea \\ ${ }^{b}$ Research Institute of biomimetic Sensory Control, Catholic University of Daegu, Gyeongsan, Korea \\ ${ }^{c}$ Catholic Hearing Voice Speech Center, Catholic University of Daegu, Gyeongsan, Korea
}

Correspondence: Chul-Hee Choi, $\mathrm{PhD}$ Department of Audiology \& Speech-Language Pathology, Catholic University of Daegu, 13-13 Hayang-ro, Hayang-eup, Gyeongsan 38430, Korea Tel: +82-53-850-2541

Fax: +82-53-850-2540

E-mail: cchoi@cu.ac.kr

Received: October 5, 2015

Revised: November 24, 2015

Accepted: December 8, 2015

This work was supported by research grants from the Catholic University of Daegu.

\begin{abstract}
Objectives: Voice onset and offset include dynamic changes of aerodynamic and biomechanical properties showing irregular and chaotic voice signals during phonation. This preliminary study investigated voice onset and offset patterns based on gender using highspeed digital imaging. Methods: Pattern analysis was performed with 40 adults. A total of 80 images ( 40 voice onset, 40 voice offset) were analyzed by two speech-language pathologists specialized in voice. Results: The most predominant pattern of voice onset was Type I (nearly simultaneous initiation of vocal folds vibration with the contact of arytenoid cartilages) in all male and female groups, followed by Type II (delayed initiation of vocal folds vibration after contact of arytenoid cartilages) in both groups. Type III voice onset, characterized by the initiation of vocal folds vibration before contact of arytenoid cartilages was only identified in one normal female. On the other hand, Type I, II, and III voice offset patterns were represented in all gender groups. Type I (simultaneously complete cessation of vocal folds vibration with abduction of arytenoid cartilages) was most frequently detected, followed by Type III (abduction of arytenoid cartilages before the cessation of vocal folds vibration), followed by Type II (delayed abduction of arytenoids after complete cessation of vocal folds vibration). However, there was no significant difference between the two gender groups in voice onset and offset patterns $(p>.05)$. Conclusion: Accordingly, the present study may be useful to provide preliminary normative data regarding voice initiation and cessation in Korean young adults.
\end{abstract}

Keywords: Voice onset, Voice offset, High-speed digital imaging, Normal young adults, Arytenoids movement
True vocal fold position is critical for phonation as the sound source. The arytenoid cartilages can control the movement of the vocal folds which influence the position and tension of the vocal folds. The vocal folds abduction or adduction can be accomplished through the rocking, gliding, or rotating motion of arytenoid cartilages. During adduction, the arytenoid cartilages allow the vocal folds to move to the midline for optimal voice production. Conversely, arytenoid cartilages move in the opposite way during abduction by moving the vocal folds laterally to secure the airway
(Woodson, 2011). The vocal folds vibration initiates when they are adducted to the midline and vibration is induced by aerodynamic phenomena. Air pressure from the lungs and the 'Bernoulli effect' generate the vibratory cycles repeatedly if subglottal air pressure is consistently maintained (Titze, 1980; Van den Berg, 1957).

Normal vocal fold vibration produces complex and diverse patterns from voice onset to offset during phonation. Voice onset and offset include dynamic changes of aerodynamic and biomechanical properties according to the underlying laryngeal configuration 
during phonation (Regner, Tao, Zhuang, \& Jiang, 2008). In addition, voice onset and offset have clinical significance for voice and speech disorders (Gallena, Smith, Zeffiro, \& Ludlow, 2001; McGee, Hutchinson, \& Deputy, 1981; Stepp, Merchant, Heaton, \& Hillman, 2011). Nevertheless, there is a lack of understanding of voice onset and offset phenomena. Vocal fold adductory gestures have been studied based on different voicing onset types: breathy, normal, and hard related to hypo- or hyper-functional voice. These perceptual characteristics of voice onset affect control of laryngeal gestures. More forceful closure and slower adduction are found in hard glottal closure than breathy or normal closure and posterior glottal chink is evident in breathy voice onset (Von Leden \& Werner-Kubuk, 1970; Wittenberg, Moser, Tigges, \& Eysholdt, 1995). In addition, Köster, Marx, Gemmar, Hess, \& Künzel (1999) studied voice onset characteristics with only one healthy female in breathy and normal onset conditions with high-speed imaging and they found that in breathy onset conditions, the remaining glottal chink in the posterior glottal area was larger than normal, which was a similar outcome to Wittenberg et al. (1995). Cooke, Ludlow, Hallett, \& Selbie (1997) measured voice onset characteristics for vocal fold adduction using a laryngoscope with 10 healthy young subjects (5 males and 5 females) and they found significant differences in gesture duration for moving maximum distance during adduction, maximum velocity, and latency between vocal fold closure and the onset of vibration of the vocal folds among the different phonatory onset type. Another study on voice onset was investigated by Tigges, Wittenberg, Mergell, \& Eysholdt (1999) using digital videokymography. They defined voice onset period as the interval from the prephonatory adduction movement to the initial point of steady vibration and they observed the vibratory pattern at the midpoint without anterior and posterior modes.

Although several studies on laryngeal dynamics of voice onset refer to perceptual categories, the majority of studies observed laryngeal behaviors with small numbers of subjects and no studies addressed gender difference's effect on voice onset characteristics.

For clinical applicability of the vocal folds vibration measurement, electroglottography (EGG), videokymography (VKG), stroboscopy, and high-speed digital imaging (HSDI) have been widely used. EGG is an invasive vocal fold vibrating measurement method which gives information on the closure and opening of vocal folds by measuring the electrical resistance between two vocal folds (Baken, 1992; Childers \& Krishnamurthy, 1985). However, it cannot provide visual information about the vibratory patterns of laryngeal structure and function. On the other hand, stroboscopy, VKG (Švec, Šram, \& Schutte, 2007), and HSDI can visualize the vocal fold vibration behavior directly (Krausert et al., 2011). Direct visual observation of vocal fold vibration provides useful information for understanding the phonatory mechanism during phonation. Visualization of vocal fold vibratory behaviors underpins the diagnosis of laryngeal pathology and is used as the basis of treatment.

The vibration of vocal folds is a fast and complex movement occurring 100-450 times a second. To visualize the fast movements of the vocal folds, laryngeal stroboscopy has been most widely used. Although it is one of the most invaluable and state-of-the-art techniques currently available for the investigation of vocal fold vibration, it produces apparent motion which appears as an optical illusion that is actually derived from several segments of different cycles which merge to provide an average vibratory pattern (Bless, Hirano, \& Feder, 1987; Olthoff, Woywod, \& Kruse, 2007; Patel, Dailey, \& Bless, 2008). It gives potential clinical information such as the glottal closure pattern or glottal gap, phase symmetry, phase closure, regularity, mucosal wave, vibratory amplitude, vocal fold height differences (vertical level), and vocal process position during phonation. However, stroboscopy cannot visualize the vibratory function in voice initiation and offset because pulsing lights emit at a frequency that is $0.5 \mathrm{~Hz}$ or $1.5 \mathrm{~Hz}$ lower than the fundamental frequency, causing a delay in the portion of each vibratory cycle illuminated which allows the vocal folds to appear to be in slow motion (Bless et al., 1987).

With the advent of the new visualization technology HSDI, there is the possibility of visualizing the real vocal fold vibration with a high sampling rate of successive frames and better spatial resolution (Hertegård, 2005; Kendall, 2012). HSDI is a frequencyindependent visualization technique, making it the only reliable visualization technique for capturing detailed irregular or chaotic vibratory behaviors to improve assessment of vocal fold function (Choi \& Choi, 2012; Kendall, 2009, 2012; Patel et al., 2008; Patel, Dubrovskiy, \& Döllinger, 2014). In general, stroboscopy is less helpful to analyze the voice onset and offset because they do not include regular phonatory cycles which can be tracked from the 
stroboscopy light source and are also associated with a rapidly changing fundamental frequency and amplitude (Choi, Lee, Sprecher, \& Jiang, 2012). Therefore, HSDI technique can provide more useful information regarding voice onset and offset.

In this study, HSDI was used to identify voice onset and offset from 40 normal speakers. Voice onset and offset patterns were analyzed qualitatively based on arytenoid cartilage movements. Voice onset and offset patterns were compared between the genders.

\section{METHODS}

\section{Participants}

A total of 40 adults consisting of 20 healthy males, age 20 to 28 years old (mean of $22.7 \pm 4.5$ ) and 20 healthy females age 20 to 26 years old (mean of $21.9 \pm 3.1$ ) participated in the study. All participants were nonsmoking native speakers of Korean. They reported normal hearing ability, no laryngeal or airway infection and negative histories of vocal pathology, and none were professional voice users. All subjects had normal-appearing vocal folds confirmed by an otolaryngologist and also were judged to present 'G0' as the normal voice quality in GRBAS as determined by two certified speech-language pathologists specializing in voice disorders. Participants were excluded from the study if they showed severe gag reflex or epiglottis covering the vocal folds.

\section{High-Speed Digital Imaging}

The vocal folds vibration was measured using KayPENTAX Color High-Speed Video System and Component Model 9710 (Kay Elemetrics Corp., Lincoln Park, NJ, USA). A sustained vowel /i/ was recorded for 4 sounds at a comfortable pitch and loudness for the participant. Typical voice production was judged by the examiner through perceptual judgments of sustained vowels and connected speech. The recording was performed and saved with a sampling rate of 1,000 frames per second with a spatial resolution of $512 \times 512$ pixels for a maximum duration of 4 seconds. The camera was coupled to a 70 PENTAX rigid type endoscope with a Xenon light source of $300 \mathrm{~W}$.

To minimize the variability of voice initiation, participants were asked to breathe in prior to the /i/ vowel phonation. Thus, no participants inhaled during phonation. After practicing, three trials were recorded for each participant. Only one representative sample of typical phonation per participant was analyzed (Patel et al., 2014). Figure 1 shows the montage image of irregular and regular vocal fold vibration of a male participant during voice onset.

\section{Subjective pattern analysis}

Voice onset and offset segments were obtained from the saved images using Photron FASTCAM Viewer (PFV) ver. 327 to analyze the pattern of voice onset and offset. Two playlists were prepared, containing 80 images (20 males voice onset, 20 females voice onset, 20 males voice offset, and 20 females voice offset) in random order. Two speech-language pathologists with clinical specialization in voice disorders (3-10 years) and more than twoyear experience with stroboscopy analyzed the voice onset and offset patterns. Sometimes whole vocal fold vibratory behaviors from the vocal process of the arytenoid cartilages to the anterior commissure were not identified by the epiglottis in some participants. For this reason, multiple tokens were recorded, and we selected the best image for analyzing the vocal fold vibratory behavior. In this study, vocal onset gesture was defined as the interval that the initial movement of the vocal folds from resting position, especially, the most open state of the glottis following the end of inspiration into regular vibration (Kunduk, Yan, Mcwhorter, \& Bless, 2006). In addition, Kunduk et al. (2006) evaluated the voice onset gesture and they found that the first vocal fold contact was followed by an irregular vibration which organized into a regular vibration as shown in the Figure 1.

The voice offset gesture, on the other hand, is regarded as the interval from complete cessation of vocal fold vibration or abduction of the arytenoid cartilages to the maximum glottis opening in the present study.

Pattern analysis was completed in a single setting. If needed, each rater controlled the rate of imaging presentation and was able to pause. Pattern analysis was conducted by each rater separately. After that, if some disagreement occurred following the first judgment, the raters discussed until the raters reach the consensus.

\section{Inter-rater reliability}

Eight images corresponding to $20 \%$ of the total laryngeal imaging were randomly selected to measure the voice onset and offset 


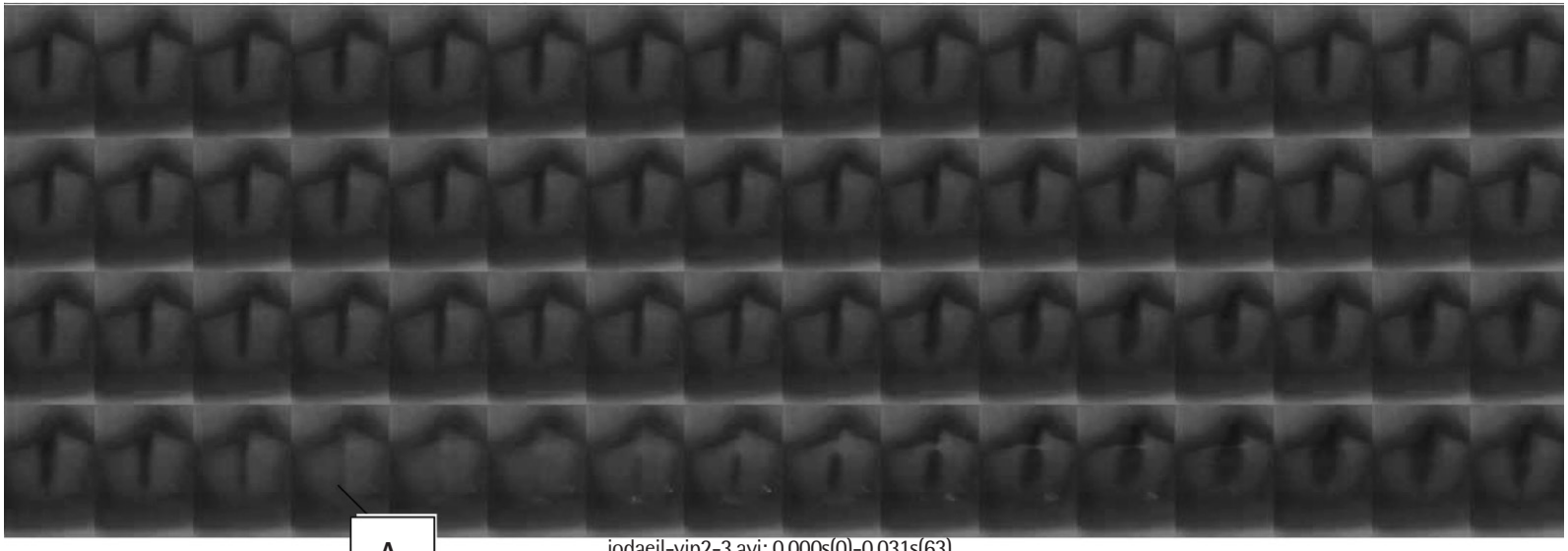

A

B

jodaeil-vip2-3.avi: 0.031s(63)-0.062s(126)

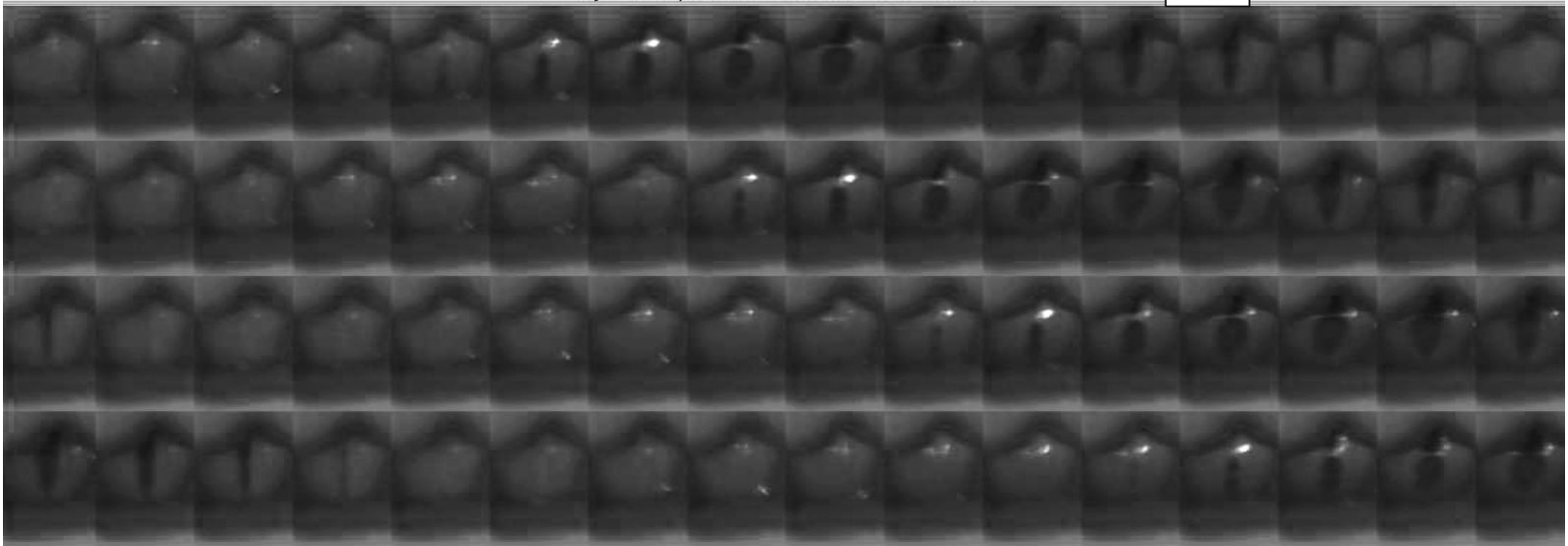

jodaeil-vip2-3.avi: 0.062s(126)-0.094s(189)

Figure 1. The montage of irregular and regular vocal fold vibration of a male participant during voice onset $(A=$ starting point of irregular vocal fold vibration; $\mathrm{B}=$ starting point of regular vocal fold vibration).

patterns for inter-rater reliability using Cohen's kappa. There was a high interrater agreement present $(\kappa=0.92)$ among the two speechlanguage pathologist raters.

Intra-rater reliability

Like interrater reliability, 8 images corresponding to $20 \%$ of the total laryngeal imaging were randomly selected to measure the voice onset and offset patterns for intra-rater reliability using Cohen's kappa and agreement was very high $(\kappa=0.96)$.

\section{Statistical analysis}

For categorical frequency data of voice onset and offset patterns, 
Fisher's exact test was conducted to investigate the differences of voice onset and offset patterns, respectively, between genders using SPSS Statistics ver. 19.0 (IBM SPSS, Armonk, NY, USA). When the expected frequency at a cell is less than 5 , it is not appropriate for conducting chi-square test. So an $\alpha$-level of 0.05 was employed.

\section{RESULTS}

\section{Pattern analysis of voice onset type}

To analyze the voice onset patterns qualitatively, voice initiation patterns were classified into three types based on time differences between arytenoid cartilages movement and initiation of vocal fold vibration. Results are shown in Figure 2.

The majority of normal adults' images were Type I voice onset pattern (67.5\%), characterized by the initiation of vocal fold vibration without any time delay (less than 100 frames in the image obtained by recording with a sampling rate of 1,000 frames per second) after the contact of arytenoid cartilages, showing the initiation of vocal fold vibration nearly simultaneously with contact of arytenoid cartilages. However, 12 Type II voice onset pattern (30\%), characterized by the initiation of vocal fold vibration with a time delay (more than 100 frames in the image obtained by recording with a sampling rate of 1,000 frames per second) following the contact of arytenoid cartilages also were identified. An additional

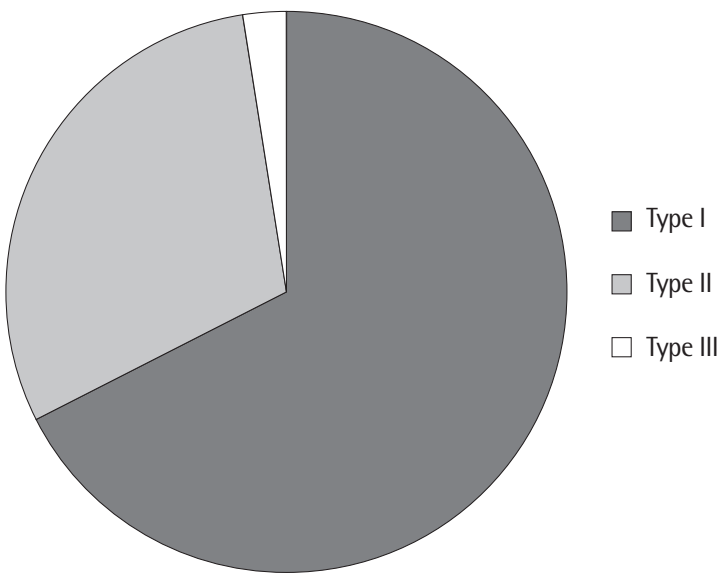

Figure 2. Voice onset patterns in normal speakers. Type I voice onset ( $N=27)$, characterized by the initiation of vocal fold vibration nearly simultaneously with the contact of arytenoid cartilages; Type II voice onset $(N=12)$, defined as the initiation of vocal fold vibration with a time delay following the contact of arytenoid cartilages; Type III voice onset pattern $(N=1)$, the initiation of vocal fold vibration before the arytenoid cartilages contact each other completely. voice onset pattern, Type III voice onset pattern was observed in only one female (2.5\%). The characterization of Type III voice onset pattern was the initiation of vocal fold vibration before the arytenoid cartilages contacted with each other completely.

\section{Pattern analysis of voice offset type}

The results of voice offset pattern analysis are shown in Figure 3. Type I voice offset pattern, characterized by complete cessation of vocal fold vibration nearly simultaneously with abduction of arytenoid cartilages, showing the arytenoid cartilage abduction following the stop of vocal fold vibration without any time delay (less than 100 frames in the image obtained by recording with a sampling rate of 1,000 frames per second) was present in 24 of 40 voice offset images, making it the most common type in normal speakers (60\%). However, 5 Type II voice offset patterns (12.5\%), characterized by the arytenoid abduction following the cessation of vocal fold vibration with a time delay (more than 100 frames in the image obtained by recording with a sampling rate of 1,000 frames per second) and eleven Type III voice offset patterns (27.5\%) in which arytenoid cartilages were abducted before the cessation of vocal fold vibration were also identified.

\section{Comparison of voice onset pattern between genders}

When analyzed by gender, Type I voice onset type was identi-

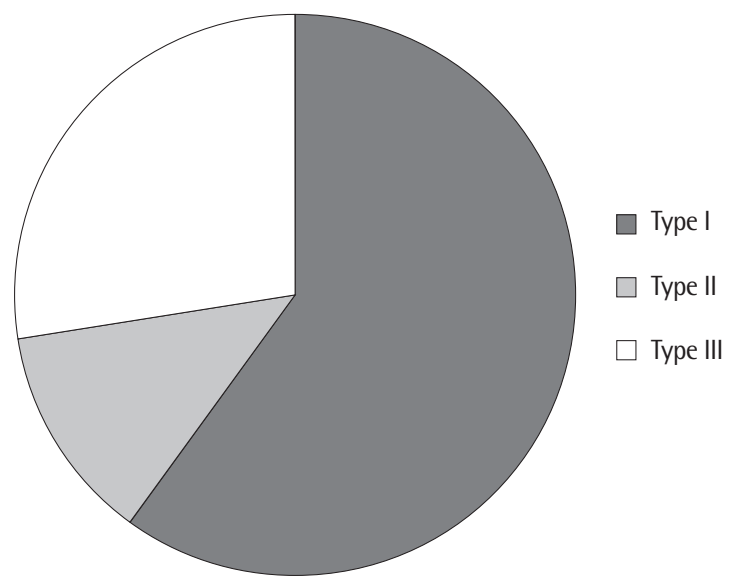

Figure 3. Voice offset patterns in normal speakers. Type I voice offset ( $N=24)$, characterized by complete cessation of vocal fold vibration nearly simultaneously with abduction of arytenoid cartilages; Type II voice offset $(\mathrm{N}=5)$, defined as abduction of arytenoids with a time delay after complete cessation of vocal fold vibration; Type III voice offset pattern $(\mathrm{N}=11)$, referring to vocal fold vibration remaining after initiation of abduction of arytenoid cartilages. 
Table 1. The results of Fisher's exact test in classification of voice onset types based on gender

\begin{tabular}{lcclccc}
\hline & Type I & Type II & Type III & $\chi^{2}$ & $d f$ & $p$-value \\
\hline Males $(\mathrm{N}=20)$ & $16(80.0)$ & $4(20.0)$ & $0(0)$ & 2.221 & - & .320 \\
Females $(\mathrm{N}=20)$ & $11(55.0)$ & $8(40.0)$ & $1(5.0)$ & & & \\
\hline
\end{tabular}

Values are presented as number (\%).

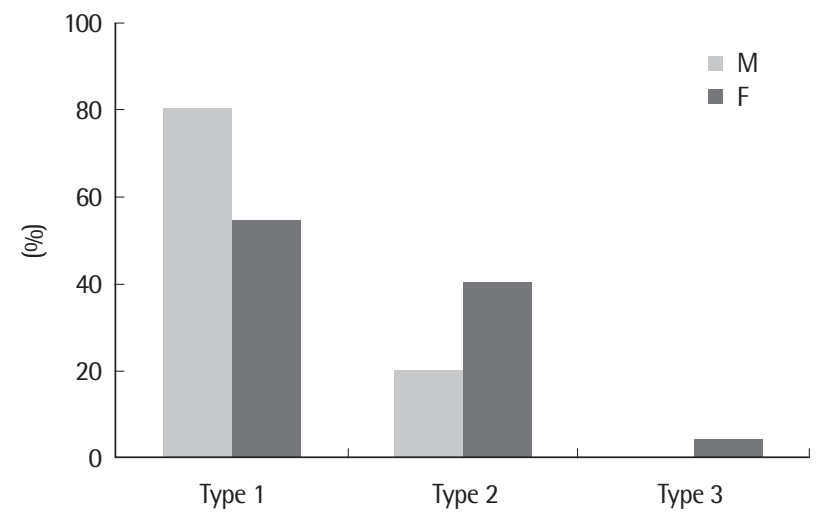

Figure 4. The percentage of voice onset patterns between genders.

fied in 16 of 20 males (80\%), making it the most common type in normal males. Type III voice onset was observed in 4 males (20\%), whereas Type III voice onset was not observed in the normal male group (Table 1).

Similarly, as shown in Table 1, in the normal female group, 11 of 20 females demonstrated Type I (55\%); 8 had Type II voice onset pattern (40\%). Interestingly, only one female had Type III voice onset pattern, characterized by the initiation of vocal fold vibration before the arytenoid cartilages contact each other completely.

As shown in Figure 4, Type I voice onset pattern was higher in normal males than females, whereas Type II voice onset pattern was lower in males than normal females. This shows that usually normal males demonstrated immediate initiation of vocal fold vibration after arytenoid cartilages adduction. In contrast, normal females had more of a time delay when initiating their vocal fold vibration after arytenoid adduction relative to males. However, Fisher exact test showed no statistically significant difference in voice onset pattern between gender groups $(p=.320)$. The results of Fisher exact test are shown in Table 1.

\section{Comparison of voice offset pattern between genders}

The percentage of each voice onset pattern by gender is shown
Table 2. The results of Fisher's exact test in classification of voice offset types based on gender

\begin{tabular}{lcccccc}
\hline & Type I & Type II & Type III & $\chi^{2}$ & df & $p$-value \\
\hline Males $(\mathrm{N}=20)$ & $9(45.0)$ & $4(20.0)$ & $7(35.0)$ & 3.915 & - & .177 \\
Females $(\mathrm{N}=20)$ & $15(75.0)$ & $1(5.0)$ & $4(20.0)$ & & & \\
\hline
\end{tabular}

Values are presented as number (\%).

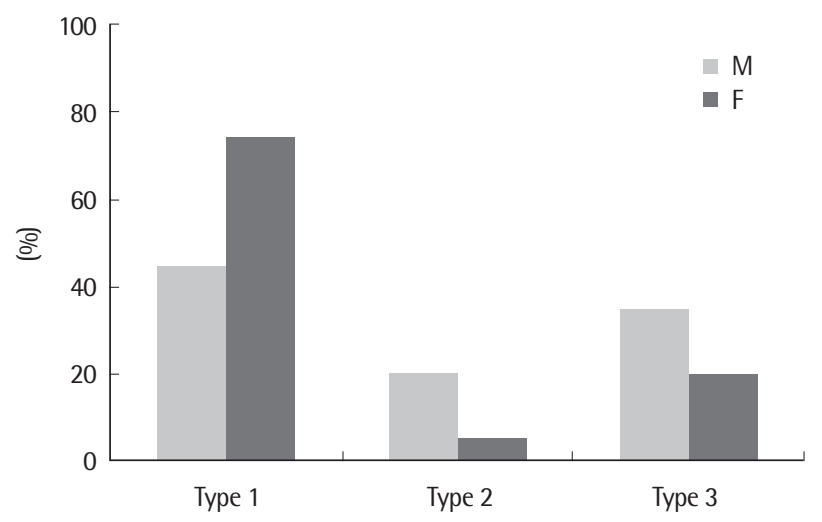

Figure 5. The percentage of voice offset patterns between genders.

in Figure 5 and Table 2. Type I, II, and III voice offset patterns were represented in both genders.

Type I voice offset pattern was most common in both gender groups; of the 20 males, 9 (45\%) had the Type I voice offset pattern, while 15 of the 20 females (75\%) demonstrated a Type I voice offset pattern. For Type II, 4 males had Type II (20\%), whereas only one female (5\%) did. Seven males (35\%) and 4 females (20\%) were observed in Type III. However, no significant difference in voice offset pattern ( $p=.177$ ) was observed between the genders (Table 2).

\section{CONCLUSION}

This study investigated how voice onset and offset were achieved during phonation with normal Korean speakers using HSDI. To measure voice onset and offset qualitatively, pattern analysis was performed based on the association between arytenoid cartilage movements and vocal fold vibration.

\section{Arytenoid cartilage movement and voice onset and offset}

The arytenoid cartilage is a pair of pyramid-shaped pieces of cartilage, which are essential to the production of vocal sound (Boone, McFarlane, Von Berg, \& Zraick, 2010). The arytenoid cartilages 
allow vocal folds to separate (abduction) for breathing or come together (adduction) for phonation, swallowing, and coughing.

Although the current understanding of the role of arytenoid cartilages for phonation has been established, the understanding of voice onset and offset during phonation is still incomplete.

In a previous study, Kunduk et al. (2006) defined the voice initiation period as the time period from the initial movement of the vocal folds from resting position to regular vibration. On the other hand, voice offset period referred to the time from the first abduction motion of the arytenoids to complete cessation of vocal fold oscillation. From those definitions, we were not able to determine the voice onset and offset in the present study. As mentioned earlier, our results demonstrated that although Type III voice offset patterns in which arytenoid cartilages were abducted before the cessation of vocal fold vibration were detected, Type I voice offset pattern, characterized by nearly simultaneous complete cessation of vocal folds vibration with abduction of arytenoid cartilages was most predominant in both genders and Type II voice offset patterns (arytenoid cartilages abduction after the cessation of vocal fold vibration) also were identified in normal adults. This may imply that the arytenoid abduction is not necessary to cease the vocal fold vibration.

Voice onset patterns demonstrated diversity among normal young adults in this study. During voice onset, vocal folds were coming into contact for phonation from resting position and then initiated the irregular vocal fold vibration and finally changed into regular vibration. In this study, the most common voice onset pattern was Type I voice onset that vibration onset nearly coincided with contact of arytenoid cartilages. However, Type II voice onset pattern, characterized by the initiation of vocal fold vibration with a time delay after the contact of arytenoid cartilages also were identified. In addition, one female revealed the initiation of vocal fold vibration before the arytenoid cartilages contacted each other completely during voice onset (Type III voice onset). Since it was found in one female in our present study, it is likely that the contact of arytenoid cartilages is not required for voicing initiation. In addition, the latency between vocal fold closure and the onset of vocal fold vibration was varied across the participants. This may relate to the timing or speed for vibratory onset, which may depend on the onset of airflow, subglottal pressure, and muscle tension (Cooke et al., 1997; Köster et al., 1999). Simultaneous analysis may help build up extensive knowledge for understanding the phonatory onset and offset behavior. Furthermore, we found that the glottal location of voice onset differed across the subjects. In future studies, the glottal location and shape can be analyzed during voice onset and offset with a glottal analysis program to clarify the dynamic vocal fold behavior.

\section{Clinical implications of gender differences in voice onset and offset}

Our data does not achieve statistical significance with respect to gender patterns in voice onset and offset. However, our findings may have some clinical implications for voice onset and offset regarding gender. In the current study, normal males, in general, demonstrated immediate initiation of vocal fold vibration after arytenoid cartilage adduction while normal females had a time delay to initiate their vocal fold vibration after arytenoid adduction during voice onset. There is some possibility that females usually demonstrate posterior glottal gap closure patterns which require more time to build up the subglottal pressure to vibrate the vocal folds. Choi \& Choi (2012) reported that a large number of Korean females showed posterior glottal gaps whereas complete glottal closure was observed mostly in Korean males. Although the arytenoid cartilages were adducted, a time difference was observed in the initiation of the vocal fold vibration among genders in our study. Clinically, arytenoid adduction has been widely used for the surgical treatment of unilateral paralytic dysphonia with laryngeal framework surgery such as type I thyroplasty (Isshiki, Tanabe, \& Sawada, 1978; McCulloch, Hoffman, Andrews, \& Karnell, 2000; Su, Tsai, Chuang, \& Chiu, 2005). The recent study using HSDI showed that arytenoid adduction surgical procedures corrected the vocal folds asymmetry and improved differences in vibration frequency and asymmetrical vibratory patterns between the vocal folds (Kimura et al., 2010). In addition, medialization thyroplasty with arytenoid adduction suture significantly improved phonation duration and aerodynamic measures (airflow, maximum phonation time) in all participants (Stow, Lee, \& Cole, 2012). Another animal study showed that medialization laryngoplasty with arytenoid adduction led to the greater improvements in phonatory parameters than that of injection laryngoplasty or medi- 
calization laryngoplasty only (Hoffman, Witt, Chapin, McCulloch, \& Jiang, 2010), which may indicate the clinical significance of the role of arytenoid cartilages for voice production, in particular, voice initiation and maintenance of voice production. As mentioned earlier, one female demonstrated, even before the arytenoid cartilages contact each other completely, the initiation of vocal folds vibration. Our results indicate that arytenoid adduction patterns during phonation may be different between genders, suggesting that for phonation improvement, it may be necessity to consider the gender effect of medicalization surgical procedures with arytenoid adduction.

Moreover, Type I voice offset pattern, characterized by abduction of arytenoid cartilages right after complete cessation of vocal fold vibration was most common in both gender groups. Regarding gender, Type I voice offset pattern was identified more in females, whereas Type II, showing delayed arytenoid abduction following the cessation of vocal fold vibration, was observed more in males than females. These phenomena may relate to phase closure in vocal fold vibration. Our previous study revealed that males showed a much longer closed phase than that of females (Choi \& Choi, 2012). Therefore, arytenoid abduction was achieved after complete vocal fold cessation in males. For Type III, males demonstrated more often than females the arytenoid cartilages which were abducted before the cessation of vocal fold vibration. Even if the arytenoid abduction occurred, vocal folds still vibrate for a while. Overall, our results imply that arytenoid abduction is not a prerequisite condition for cessation of vocal fold vibration. The present study has some limitations due to the small number of subjects and being limited to young Korean adults. In the future, additional pattern analysis of voice onset and offset is needed to explore the voice onset and offset behavior of different dysphonic patients, ages, and vocal quality types.

\section{REFERENCES}

Baken, R. J. (1992). Electroglottography. Journal of Voice, 6, 98-110.

Bless, D. M., Hirano, M., \& Feder, R. J. (1987). Videostroboscopic evaluation of the larynx. Ear, Nose, \& Throat Journal, 66, 289-296.

Boone, D. R., McFarlane, S. C., Von Berg, S. L., \& Zraick, R. I. (2005). The voice and voice therapy (8th ed.). Boston, MA: Pearson Education.
Childers, D. G., \& Krishnamurthy, A. K. (1985). A critical review of electroglottography. Critical Reviews in Biomedical Engineering, 12, 131-161.

Choi, S. H., \& Choi, C. H. (2012). Qualitative analysis of vocal fold vibration in normal adults with a high-speed video system. Korean Journal of Communication Disorders, 17, 591-602.

Choi, S. H., Lee, J., Sprecher, A. J., \& Jiang, J. J. (2012). The effect of segment selection on acoustic analysis. Journal of Voice, 26, 1-7.

Cooke, A., Ludlow, C. L., Hallett, N., \& Selbie, W. S. (1997). Characteristics of vocal fold adduction related to voice onset. Journal of Voice, 11, 12-22.

Gallena, S., Smith, P. J., Zeffiro, T., \& Ludlow, C. L. (2001). Effects of levodopa on laryngeal muscle activity for voice onset and offset in Parkinson disease. Journal of Speech, Language, and Hearing Research, 44, 1284-1299.

Hertegård, S. (2005). What have we learned about laryngeal physiology from high-speed digital videoendoscopy? Current Opinion in Otolaryngology \& Head and Neck Surgery, 13, 152-156.

Hoffman, M. R., Witt, R. E., Chapin, W. J., McCulloch, T. M., \& Jiang, J. J. (2010). Multiparameter comparison of injection laryngoplasty, medialization laryngoplasty, and arytenoid adduction in an excised larynx model. Laryngoscope, 120, 769-776.

Isshiki, N., Tanabe, M., \& Sawada, M. (1978). Arytenoid adduction for unilateral vocal cord paralysis. Archives of Otolaryngology, 104, 555-558.

Kendall, K. A. (2009). High-speed laryngeal imaging compared with videostroboscopy in healthy subjects. Archives of Otolaryngology-Head \& Neck Surgery, 135, 274-281.

Kendall, K. A. (2012). High-speed digital imaging of the larynx: recent advances. Current Opinion in Otolaryngology \& Head and Neck Surgery, 20, $466-471$.

Kimura, M., Imagawa, H., Nito, T., Sakakibara, K. I., Chan, R. W., \& Tayama, N. (2010). Arytenoid adduction for correcting vocal fold asymmetry: highspeed imaging. Annals of Otology, Rhinology \& Laryngology, 119, 439-446.

Köster, O., Marx, B., Gemmar, P., Hess, M. M., \& Künzel, H. J. (1999). Qualitative and quantitative analysis of voice onset by means of a multidimensional voice analysis system (MVAS) using high-speed imaging. Journal of Voice, $13,355-374$.

Krausert, C. R., Olszewski, A. E., Taylor, L. N., McMurray, J. S., Dailey, S. H., \& Jiang, J. J. (2011). Mucosal wave measurement and visualization techniques. Journal of Voice, 25, 395-405.

Kunduk, M., Yan, Y., Mcwhorter, A. J., \& Bless, D. (2006). Investigation of voice initiation and voice offset characteristics with high-speed digital imaging. Logopedics Phoniatrics Vocology, 31, 139-144. 
McCulloch, T. M., Hoffman, H. T., Andrews, B. T., \& Karnell, M. P. (2000). Arytenoid adduction combined with Gore-Tex medialization thyroplasty. Laryngoscope, 110, 1306-1311.

McGee, S. R., Hutchinson, J. M., \& Deputy, P. N. (1981). The influence of the onset of phonation on the frequency of disfluency among children who stutter. Journal of Speech, Language, and Hearing Research, 24, 269-272.

Olthoff, A., Woywod, C., \& Kruse, E. (2007). Stroboscopy versus high-speed glottography: a comparative study. Laryngoscope, 117, 1123-1126.

Patel, R. R., Dubrovskiy, D., \& Döllinger, M. (2014). Measurement of glottal cycle characteristics between children and adults: physiological variations. Journal of Voice, 28, 476-486.

Patel, R., Dailey, S., \& Bless, D. (2008). Comparison of high-speed digital imaging with stroboscopy for laryngeal imaging of glottal disorders. Annals of Otology, Rhinology \& Laryngology, 117, 413-424.

Regner, M. F., Tao, C., Zhuang, P., \& Jiang, J. J. (2008). Onset and offset phonation threshold flow in excised canine larynges. Laryngoscope, 118, 13131317.

Stepp, C. E., Merchant, G. R., Heaton, J. T., \& Hillman, R. E. (2011). Effects of voice therapy on relative fundamental frequency during voicing offset and onset in patients with vocal hyperfunction. Journal of Speech, Language, and Hearing Research, 54, 1260-1266.

Stow, N. W., Lee, J. W., \& Cole, I. E. (2012). Novel approach of medialization thyroplasty with arytenoid adduction performed under general anesthesia with a laryngeal mask. Otolaryngology-Head and Neck Surgery, 146, 266-
271.

Su, C. Y., Tsai, S. S., Chuang, H. C., \& Chiu, J. F. (2005). Functional significance of arytenoid adduction with the suture attaching to cricoid cartilage versus to thyroid cartilage for unilateral paralytic dysphonia. Laryngoscope, 115, 1752-1759.

Švec, J. G., Šram, F., \& Schutte, H. K. (2007). Videokymography in voice disorders: what to look for? Annals of Otology, Rhinology \& Laryngology, 116, $172-180$.

Tigges, M., Wittenberg, T., Mergell, P., \& Eysholdt, U. (1999). Imaging of vocal fold vibration by digital multi-plane kymography. Computerized Medical Imaging and Graphics, 23, 323-330.

Titze, I. R. (1980). Comments on the myoelastic-aerodynamic theory of phonation. Journal of Speech, Language, and Hearing Research, 23, 495-510.

Van den Berg, J. (1958). Myoelastic-aerodynamic theory of voice production. Journal of Speech and Hearing Research, 1, 227-244.

Von Leden, H., \& Werner-Kubuk, E. (1970). Vocal initiation: high speed cinematographic studies on normal subjects. Folia Phoniatrica (Basel), 22, 107116.

Wittenberg, T., Moser, M., Tigges, M., \& Eysholdt, U. (1995). Recording, processing, and analysis of digital high-speed sequences in glottography. Machine Vision and Applications, 8, 399-404.

Woodson, G. (2011). Arytenoid abduction for bilateral vocal fold immobility. Current Opinion in Otolaryngology \& Head and Neck Surgery, 19, 428-433. 


\section{국문초록}

\section{초고속 성대촬영 이미지를 이용한 정상 성인의 발성개시와 종료에 대한 패턴 분석: 피열연골 움직임의 역할 최성희 ${ }^{1,2,3} \cdot$ 오치선 ${ }^{1} \cdot$ 최철희 ${ }^{1,2,3}$ \\ ${ }^{1}$ 대구가톨릭대학교 언어청각치료학과, ${ }^{2}$ 대구가톨릭대학교 생체모방감각제어연구소, ${ }^{3}$ 대구가톨릭대학교 가톨릭청각음성언어센터}

배경 및 목적: 발성 개시와 종료는 발성 동안 공기역학적, 생체역학적 변화를 포함하며 불규칙적이며 카오스적인 음성 신호를 보인다. 본 예비연구는 초고속 성대촬영 이미지를 이용하여 성별에 따른 발성 개시와 종료 패턴의 특징을 조사하였다. 방법: 40 명의 청년층을 대상으로 패턴 분석을 실시하였다. 두 명의 음성언어치료사가 총 80 개의 이미지(40개의 발성 개시, 40 개의 발성 종료 이미지)를 분석하 였다. 결과: 가장 두드러진 발성개시 패턴은 남녀 모든 집단에서 제I형(피열연골의 접촉과 거의 동시에 성대 진동의 시작)이었으며, 그 다 음으로는 남녀 모두 제II형(피열연골의 접촉 후 지연된 성대 진동의 시작)의 발성 개시 패턴이었다. 피열연골의 접촉 전 성대 진동이 시작 되는 특성을 보이는 제III형의 발성 개시 형태는 여성 한 명에서만 관찰되었다. 한편, 발성 종료 패턴은 모든 성별 집단에서 제I, II, III형 이 관찰되었다. 남녀 모두 발성종료 제I형(피열연골의 외전과 거의 동시에 성대 진동의 정지)이 가장 빈번히 관찰되었으며, 그 다음으로 는 남녀 모두 제III형(성대 진동의 정지 전 피열연골의 외전, 즉, 피열연골 외전 후 지연된 성대 진동)이었으며, 그 다음으로는 제II형(성대 진동의 완전한 정지 후 지연된 성대의 외전)의 패턴이었다. 그러나, 두 성별 간 발성 개시와 종료 패턴 간에 유의한 차이는 보이지 않았다 ( $p>$.05). 논의 및 결론: 따라서, 본 연구는 한국인 정상 청년층의 발성 개시와 종료 패턴에 대한 예비적인 규준 자료를 제공하는 데 유용 할 것으로 보인다.

핵심어: 발성 개시, 발성 종료, 초고속 성대 촬영 이미지, 피열연골 움직임, 정상 청년층

본 연구는 대구가톨릭대학교 교내연구비 지원으로 수행되었음. 